\title{
The Performance of the Agri-food Sector in the Recent Economic Crisis and during Covid-19 Pandemic
}

\author{
Tamás Mizik ${ }^{\mathrm{a}^{*}}$ \\ ${ }^{a}$ Agribusiness Department, Corvinus University of Budapest, Budapest 1093, Hungary.
}

Received 17 January 2021; Revised 22 April 2021; Accepted 11 May 2021; Published 01 September 2021

\begin{abstract}
Crises impact every sector of the economy; however, the magnitude of that impact varies between the different sectors. The agri-food sector-related lessons learned from the last two crises (the global financial crisis in 2008 and the sanctions against Russia in 2014) are that international trade becomes lower and commodity prices rise. This article analyzes the performance of the Hungarian agri-food sector during the last three crises, based on international and Hungarian datasets. The results show that impacts depend on many factors, such as the type of agri-food products (raw material vs. processed products, perishable vs. non-perishable goods, etc.) or the depth of trade integration. It should be noted that Hungary is heavily integrated into the EU's common market; its major trade partners are the other member states. At the commodity level, the share of raw materials is higher on the export side (e.g. cereals) compared to the import side (e.g. meat products). Based on the results, the impacts of the COVID-19 pandemic were different from the two previous crises. Despite the difficulties in transport, Hungarian exportation expanded and resulted in an increasing trade surplus, while international commodity prices remained stable. The major finding of the article is the identification of the different impacts of the coronavirus compared to the other two crises.
\end{abstract}

Keywords: Agricultural Production; Agri-Food Trade; Trade Balance; Crisis; Coronavirus Pandemic.

\section{Introduction}

Food security and, mostly in developed countries, food safety are becoming more important. Feeding the world is an enormous challenge and is expected to become an even greater predicament within a short period of time. The world population is expected to reach 10 billion by 2050, and resource-intensive farming systems can no longer be used due to their various negative environmental impacts, such as deforestation, water scarcities, soil depletion, and noticeable greenhouse gas emissions [1]. Countries with better endowments, including agricultural areas, workforce, capital, and weather conditions, are more likely to become self-sufficient. Regarding surpluses, the agri-food sector could contribute to the Net Foreign Exchange (NFE) earnings. The higher the value-added of the agri-food products is, the higher the amount the NFE could become. Therefore, the exportation of high value-added products, as well as the importation of raw materials, are key elements of international trade success. However, trade performance is highly impacted by the different crises. In the last two decades, humanity has faced numerous agri-food related crises. The most notable ones were the different animal-related pandemics (swine flu, foot-and-mouth disease, avian influenza (H5N1), African swine fever, etc.). In the case of global crises, the world financial crisis of 2007-2008, the EU sanctions against Russia in 2014, and the COVID-19 pandemic in 2020 should be mentioned. These crises hit multiple sectors of the economy. Their impacts were different in the agri-food sector. The financial crises resulted in a sharp

*Corresponding author: tamas.mizik@uni-corvinus.hu

$>$ This is an open access article under the CC-BY license (https://creativecommons.org/licenses/by/4.0/).

(C) Authors retain all copyrights. 
increase in agricultural commodity prices, they became 3-5 times higher compared to 2003 and the erosion of the purchasing power of the poorest households [2]. After the recovery, commodity prices went back. Overall, the agrifood sector turned out to be crisis-resistant [3].

The EU sanctions introduced in 2014 significantly increased the agricultural performance of the Russian Federation due to its higher strategic self-sufficiency, preferential agricultural credits, and higher producer prices [4]. This process was strengthened by other actions, such as the higher market protection provided by the ban, as well as the significant depreciation of the Russian ruble against the US dollar that improved the trade competitiveness of Russian agri-food commodities [5]. Some of those markets have been lost forever.

The impact of the recent pandemic cannot be fully evaluated due to the lack of available data for the analysis. However, the different lockdown measures and restrictions made the agri-food trade more difficult. Emerging markets and developing countries were affected more, especially if they export perishable products (flowers, fruits, and vegetables) [6]. Food retail replaced food service, which resulted in the closure of the hospitality channel and caused panic buying [7]. The food supply chain seems to be vulnerable to this crisis, but its flexibility is a key issue in responding to the present and future challenges [8]. But the first, dramatic impacts of this shock lasted only for a few months. Prices and production went back to near normal in e.g. North America (Canada, USA). However, flexibility seems to be the most important element of the future's supply chain [7]. Continuously operating dialogues between the different stakeholders is a prerequisite on this path [9]. These crises may accelerate regional integration, especially for resource abundant countries [10]. According to Heck et al. (2020), building resilience also has utmost importance, e.g. by diverting production capacities from the export-dependent, non-food sub-sectors to local food production [11].

With respect to trade restrictions, having an agri-food trade surplus helps reach a satisfactory food security level. According to Verpoorten et al. (2013), higher food prices improved the food security of the net food producers [12]. They also found that strong GDP growth can offset the negative impacts of high food prices. However, these impacts vary between the countries, as well as sectors. Significant production surpluses can help feed the population but can also cause serious issues. For example, the Dutch cut flowers and potatoes markets collapsed, and the switch from the previous distribution channels to the new ones (supermarkets, online) was difficult [13]. Short term consequences are limited only if (i) farmers have access to the different inputs; (ii) food flowing is provided, and (iii) workforce migration is granted [11].

Daglis et al. (2020) analyzed the global impacts of the coronavirus on the oat and wheat markets and identified a positive effect, meaning that the COVID-19 pandemic was a significant contributor to the price growth [14]. In such a case, governmental actions are important. Targeted recovery plans help achieve maximum output, and the increase of agri-food production capacities for the net importing countries, such as Croatia, may substantially reduce the negative impacts of different crises on the countries [15]. However, there are many other factors that may help to mitigate these negative impacts, such as infrastructure (transportation, Internet) and the development of the food supply chain [16]. Although the current pandemic has not caused permanent food shortages, the decrease of the consumers' income made food buying more difficult [17].

From the agricultural point of view, there are many different options available for reaching these objectives:

- Improvement of education and advisory services;

- Investment supports (machinery and buildings);

- More efficient production (e.g. high-quality seeds; precision farming, especially tailored input use according to the needs of the soil and plants; better post-harvest management, etc.);

- Higher level of processing (value added) and improvement of the food industry;

- Improvement of the agri-food trade.

The paper aims to answer the following research questions: Is agri-food trade surplus an advantage or rather a disadvantage? Does this depend on trade relations and trade structure? What would be recommended to deal with a crisis? The structure of the paper is as follows. The second section introduces the material and methods used. The third section gives an overview of the Hungarian agricultural sector differentiating between the major crop (maize, wheat, and sunflower) and animal products (chicken meat, pork, and cow milk). The fourth section analyzes the Hungarian agri-food trade by providing information on the importance of the agri-food trade; imports, exports, trade balance; major trade partners, and the main import and export product groups. The final section concludes and provides recommendations based on the obtained results.

\section{Material and Methods}

The article uses free and publicly available data sources. Regarding the country-related issues (production structure and basic agricultural indicators), we used datasets from the Hungarian National Statistical Office. Production and yield data rely on the data of the Food and Agriculture Organization. Finally, all the agri-food trade data was derived 
from the World Bank's World Integrated Trade Solution database. For the period of 2000 to 2019, HS-2 level data was downloaded for agri-food products (Chapters 1-24). Table 1 shows the codes of these product groups.

Table 1. Codes of product groups by HS-2 classification [18]

\begin{tabular}{|c|c|}
\hline Product groups & Code \\
\hline Meat and edible meat offal & 2 \\
\hline Fish and crustaceans, molluscs and other aquatic invertebrates & 3 \\
\hline Dairy produce, birds' eggs, natural honey, edible products of animal origin not elsewhere specified or included & 4 \\
\hline Products of animal origin, not elsewhere specified or included & 5 \\
\hline Edible vegetables and certain roots and tubers & 7 \\
\hline Edible fruit and nuts, peel of citrus or melons & 8 \\
\hline Coffee, tea, mat and spices & 9 \\
\hline Cereals & 10 \\
\hline Vegetable plaiting materials, vegetable products not elsewhere specified or included & 14 \\
\hline Animal or vegetable fats and oils and their cleavage products, prepared edible fats, animal or vegetable waxes & 15 \\
\hline Preparations of meat, of fish or of crustaceans, molluscs or other aquatic invertebrates & 16 \\
\hline Sugar and sugar confectionery & 17 \\
\hline Cocoa and cocoa preparations & 18 \\
\hline Preparations of cereals, flour, starch or milk, pastrycooks' products & 19 \\
\hline Preparations of vegetables, fruit, nuts or other parts of plants & 20 \\
\hline Miscellaneous edible preparations & 21 \\
\hline
\end{tabular}

Figure 1 summarizes the major elements of the research in a form of a flowchart.

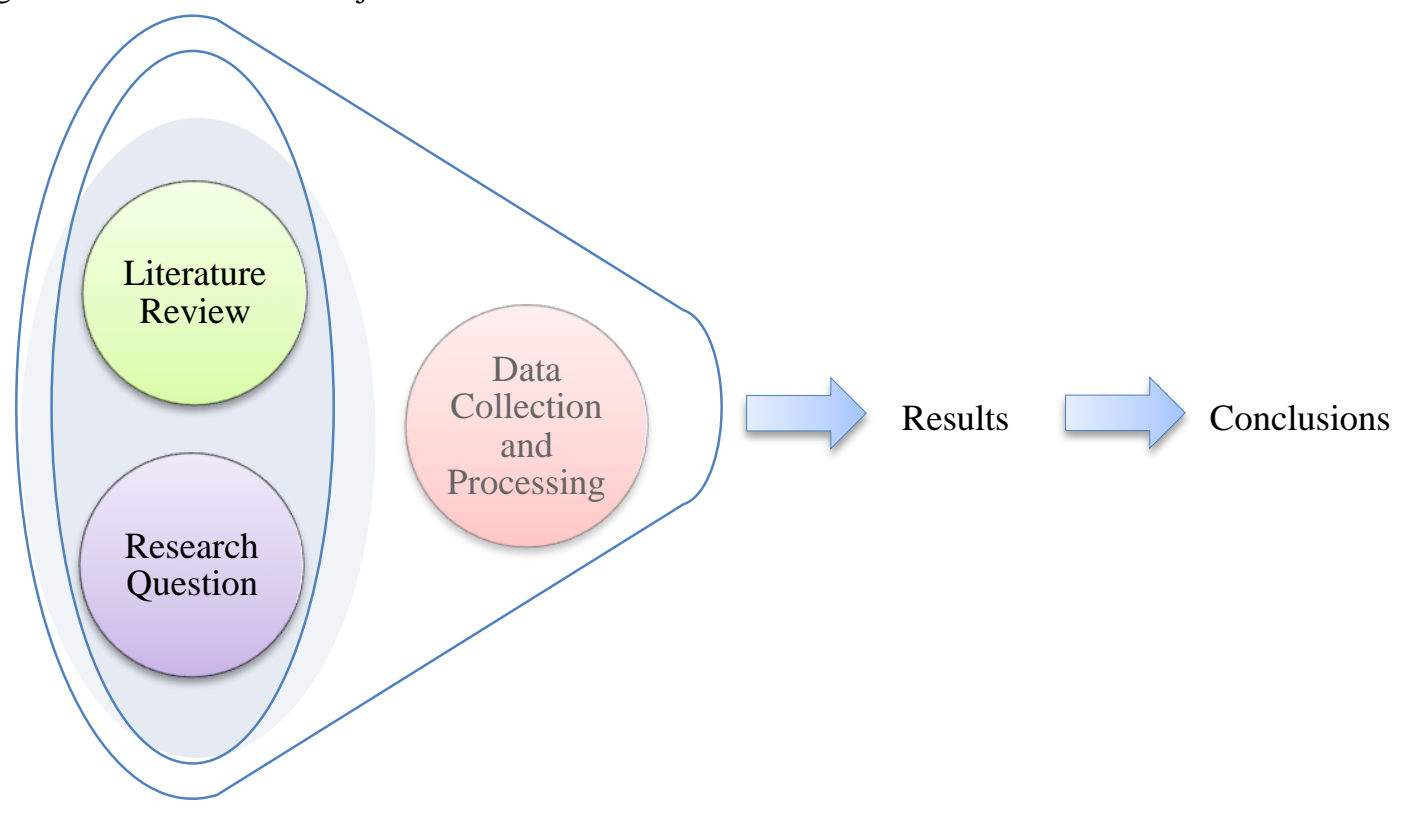

Figure 1. Flowchart of the research methodology

\section{Major Characteristics of Hungarian Agriculture}

Hungarian agriculture can be characterized by the large number of small, mostly individual, farms and a lesser amount of large, mostly corporate, farms. This is the dual production system. Table 2 summarizes the results of the last seven farm structure services (2003, 2005, 2007, 2013 and 2016) and agricultural censuses (2000 and 2010). 
Table 2. Number and size of agricultural units, 2000-2016* [19]

\begin{tabular}{|c|c|c|c|c|c|c|c|}
\hline & 2000 & 2003 & 2005 & 2007 & 2010 & 2013 & 2016 \\
\hline No. of private holdings & 958,534 & 765,608 & 706,877 & 618,651 & 561,030 & 479,166 & 421,870 \\
\hline No. of agricultural enterprises & 6,954 & 7,813 & 7,927 & 7,405 & 7,970 & 8,090 & 9,388 \\
\hline Land use, privates (ha) & $2,614,327$ & $2,357,689$ & $2,355,326$ & $2,262,824$ & $2,418,537$ & $2,467,616$ & $2,724,350$ \\
\hline Land use, enterprises (ha) & $3,833,829$ & $3,472,092$ & $3,800,909$ & $3,740,724$ & $2,191,548$ & $2,121,676$ & $1,945,917$ \\
\hline Average land size, privates (ha) & 2.73 & 3.08 & 3.33 & 3.66 & 4.31 & 5.15 & 6.46 \\
\hline Average land size, enterprises (ha) & 551.31 & 444.40 & 479.49 & 505.16 & 274.97 & 262.26 & 207.28 \\
\hline National average land size (ha) & 6.68 & 7.54 & 8.61 & 9.59 & 8.10 & 9.42 & 10.83 \\
\hline
\end{tabular}

* The final results of the Agricultural Census 2020 are not yet available.

Based on the data above, the production units show a sharply decreasing trend. However, this trend can be separated into two categories: individuals (private holdings) and agricultural enterprises. The former decreased by more than half from 2000 to 2016, while the latter increased by $35 \%$ in the same period. There was a remarkable consolidation of the individual producers, resulting in fewer farmers and higher average land sizes. Although the average farms sizes more than doubled, the 6.46 ha average size is still very low. This land concentration is noticeable in the other new member states as well. Contrary to individuals, the land use of enterprises shows a continuously decreasing trend. This is explained by the land law because only individuals can own agricultural land, legal entities should rent them. Up to 2007, owned and utilized land was administrated together, the last three years contain only the utilized agricultural area. Lower land use results in lower average land sizes. However, average land sizes show a remarkably sharper decrease. This process was driven by two policy changes, the maximum capping introduced over $176,000 \mathrm{EUR} /$ farm (physical farm size is 1,200 ha) and the land use limit (basically 1,200 ha) of the actual land law, resulting in splitting up the large farms in order to not lose some part of the basic payment, and to comply with the land law statutory requirement [20].

The importance of the agri-food sector can be evaluated by using two simple indicators: employment and gross value added. Figure 2 shows those values for the agriculture and food industry. This sectoral data is only available from 2008 and onwards. Before 2008, the food industry was not separated from the processing industry.

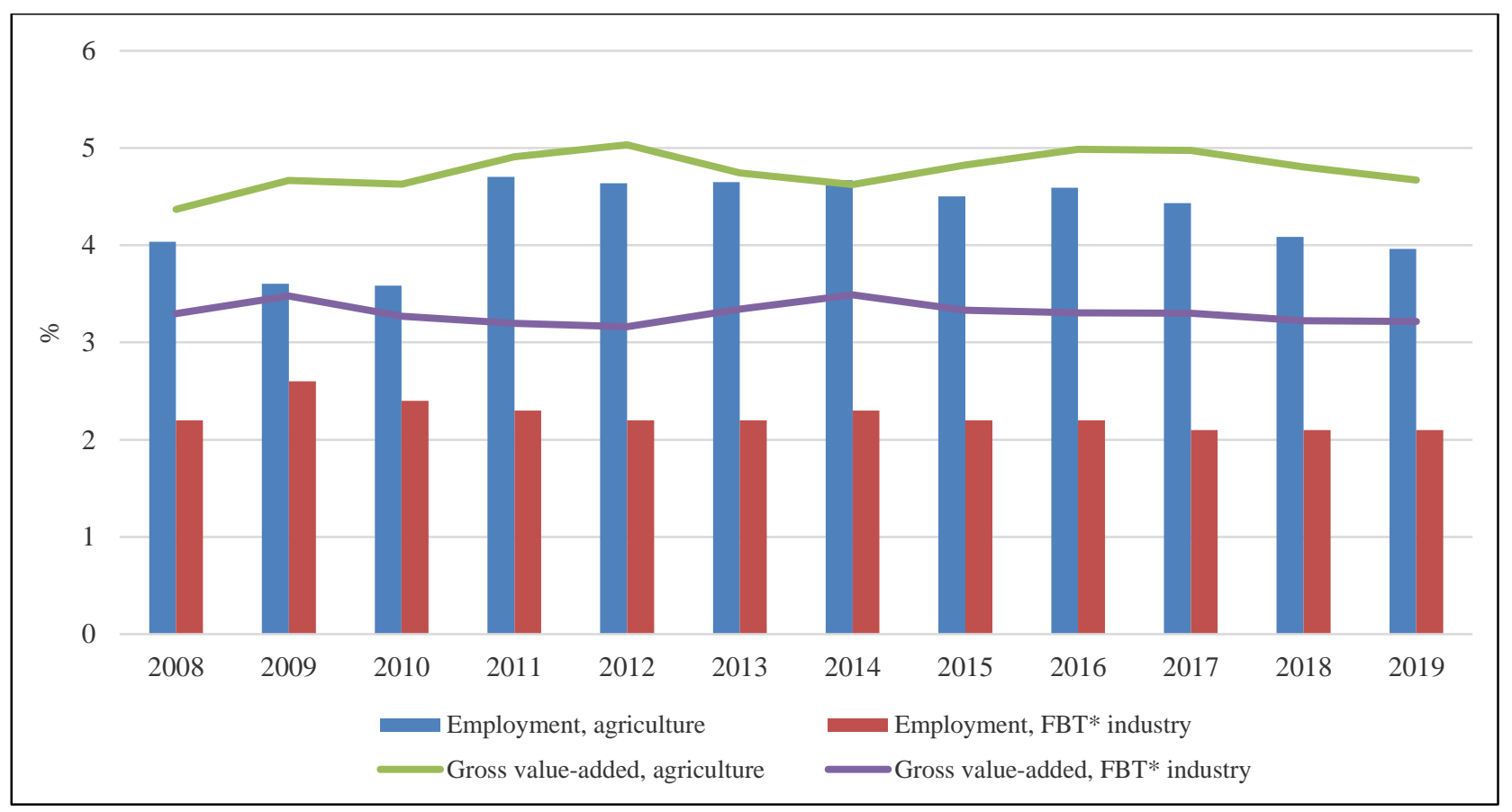

$*$ FBT $=$ Food, Beverages, and Tobacco

Figure 2. Employment and gross value-added of the agri-food sector; Source: Author's composition based on HNSO [21, 22]

Agriculture plays a more important role in the agribusiness than the food, beverages, and tobacco industry (hereinafter referred to as the food industry). Both the employment and gross value-added datasets support this finding. However, all of these values above fluctuated in a very narrow range, e.g. the share of agricultural employment was between $3.6 \%$ and $4.7 \%$, and the food industrial gross value-added remained in the range of 3.2$3.5 \%$. 
The performance of agriculture can be evaluated by its production. In the case of crop production, this is determined by two variables, production area and yield. Figure 3 provides an overview of these values for the three major crops: maize, wheat, and sunflower.

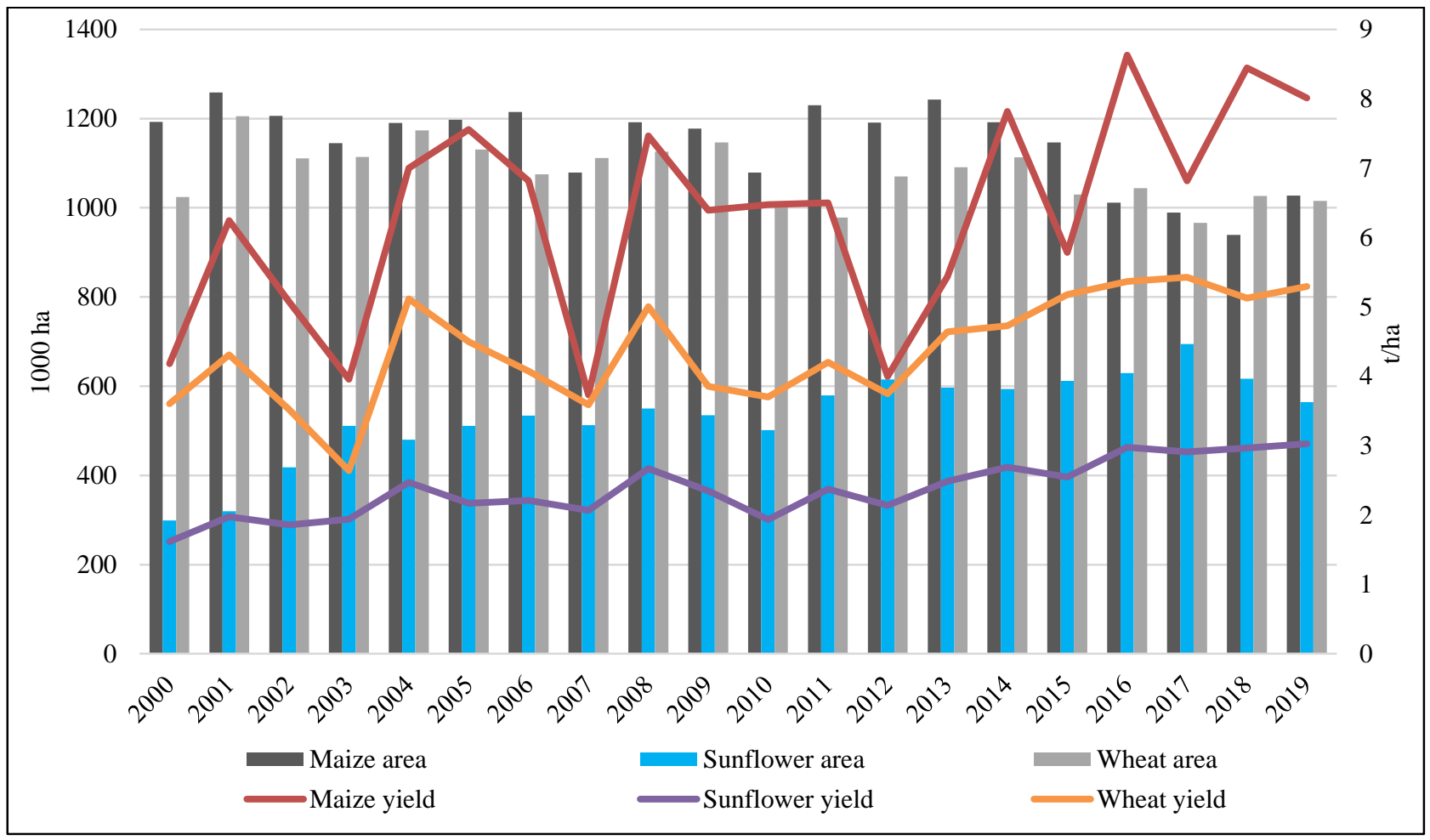

Figure 3. Area and yield of the three major crop products; Source: Author's composition based on FAO [23]

Maize has the highest production area, which was above 1 million hectares in most of the analyzed years. This crop also has the highest yield. The unfavorable weather conditions, e.g. the late snow in April and summer heat waves of 2003, drought and heat waves in 2007, and the very hot and extremely dry August of 2013, caused sharp declines in yields. Wheat and, especially, sunflower yields were lower than that of maize, even as they showed more resistance towards the extreme weather conditions. Using better production technologies and irrigating more would be the best practices for producing at higher and more stable rates.

Regarding the livestock sector, the three main "products" were analyzed: number of chickens, pigs, and cows at the animal level, while chicken meat, pork, and milk at the product level. Figure 4 shows the amount of the three major animal species, while Figure 5 illustrates the yields of their related products.

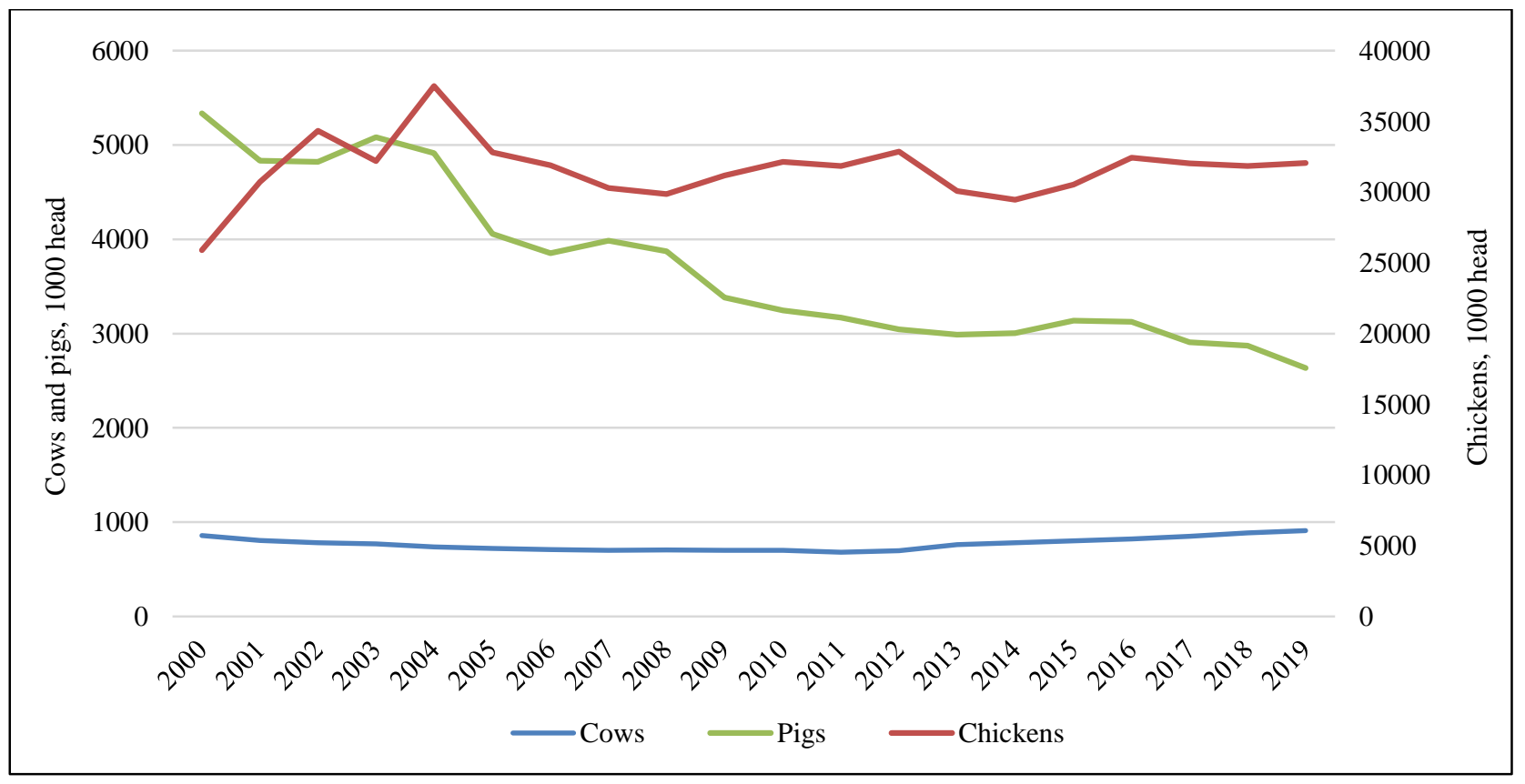

Figure 4. Amount of the three major livestock types; Source: Author's composition based on FAO [24] 
As seen above, the number of chickens, and especially cows, were stable during the analyzed period. However, the number of pigs significantly decreased from 5.3 million to 2.6 million. The reasons for this are manifold. The Hungarian EU accession accelerated this process. The increased market competition, the lack of investment supports, and market uncertainties resulted in a lower amount of pigs, especially at the level of individual producers [25]. On the other hand, the cattle sector enjoyed a high amount of coupled supports, especially the cow milking sector. This led to an enormous dependency on the supports, as the average rate of subsidy is between $130 \%$ and $170 \%$ of the pre-tax profit [26]. Regarding efficiency, chicken yield increased by $13 \%$ in the last 20 years. Pig yield was already high in 2000, therefore, further increase did not occur. Milk yield increased enormously in 2012, from 5,381 1/animal/year to 6,985 1/animal/year [27]. The increasing trend lasted until 2018, and decreased slightly in 2019.

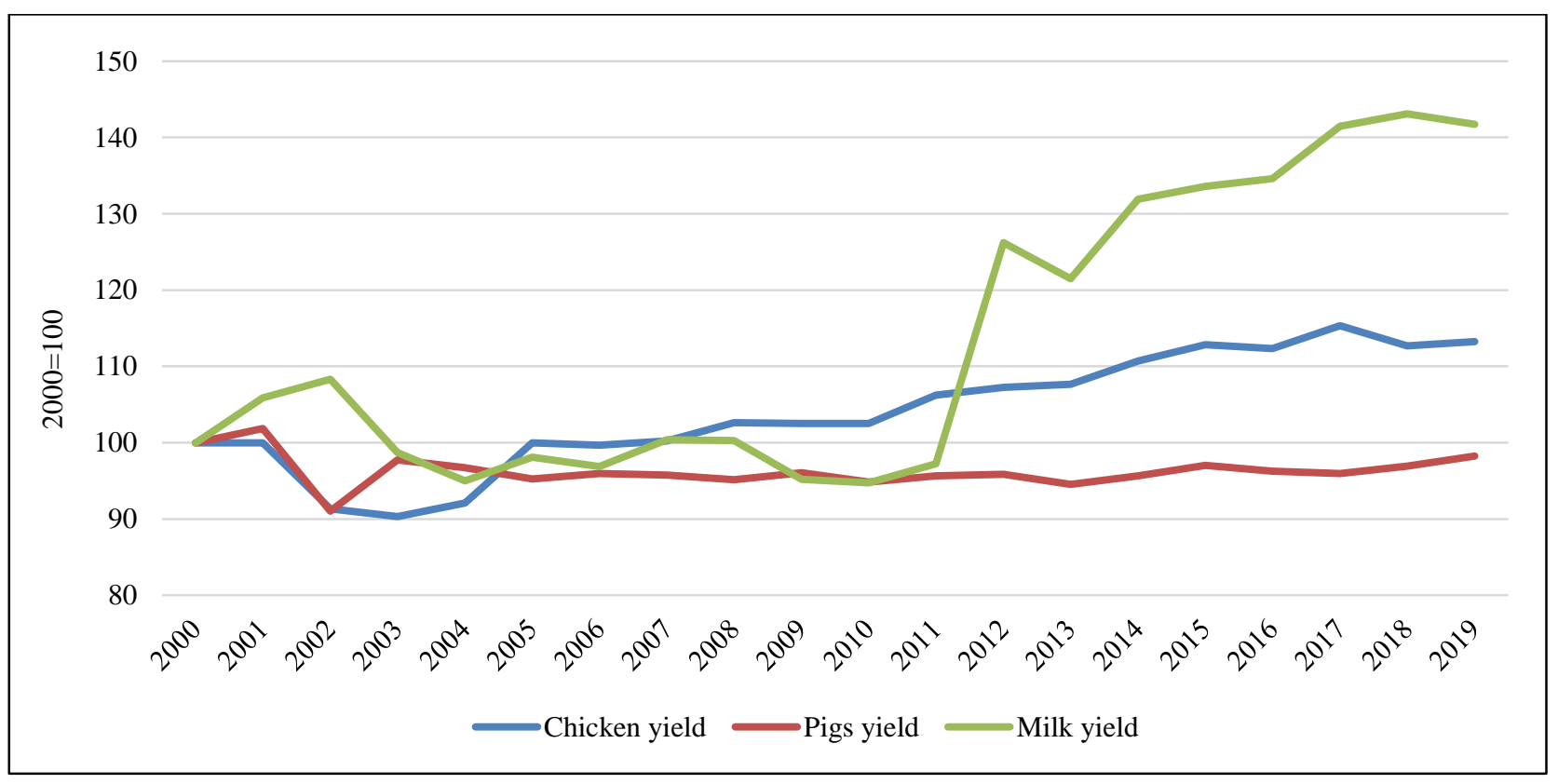

Figure 5. Yield changes of the three major livestock products; Source: Author's composition based on FAO [27]

\section{Hungarian Agri-food Trade Performance}

As an EU member state, Hungary has tight trade relations with the other member states. This can be measured if we compare the import and export shares with the EU to the same shares with the whole world. Table 3 shows these ratios, as well as the relative importance of the EU.

Table 3. Importance of the agri-food imports and exports on world and EU-28 levels [18]

\begin{tabular}{cccccc}
\hline Ratios & Relations/Levels & $\mathbf{2 0 0 0 - 2 0 0 4}$ & $\mathbf{2 0 0 5 - 2 0 0 9}$ & $\mathbf{2 0 1 0 - 2 0 1 4}$ & $\mathbf{2 0 1 5 - 2 0 1 9}$ \\
\hline \multirow{2}{*}{ Agri-food export to total Hungarian export } & EU-28 & $6.65 \%$ & $6.98 \%$ & $9.49 \%$ & $9.07 \%$ \\
& World & $7.57 \%$ & $6.89 \%$ & $8.75 \%$ & $8.54 \%$ \\
\hline \multirow{2}{*}{ Export share of the EU-28 } & Agri-food & $74.54 \%$ & $81.39 \%$ & $84.21 \%$ & $84.92 \%$ \\
& Total & $84.76 \%$ & $80.75 \%$ & $77.78 \%$ & $79.96 \%$ \\
\hline \multirow{2}{*}{ Agri-food import to total Hungarian import } & EU-28 & $3.68 \%$ & $6.12 \%$ & $6.99 \%$ & $7.24 \%$ \\
& World & $3.51 \%$ & $4.60 \%$ & $5.37 \%$ & $5.97 \%$ \\
\hline \multirow{2}{*}{ Import share of the EU-28 } & Agri-food & $70.05 \%$ & $92.60 \%$ & $92.51 \%$ & $92.45 \%$ \\
& Total & $67.20 \%$ & $69.78 \%$ & $71.10 \%$ & $76.23 \%$ \\
\hline
\end{tabular}

Hungarian agri-food exports contribute to total Hungarian exports by $6.89-8.75 \%$ on average. These shares are much lower on the import side (3.51-5.97\%). This fact demonstrates the export-oriented nature of the Hungarian agrifood sector. Agri-food trade became more important on both levels (EU-28 and world) and trade directions (import and export). The EU's importance as a trading partner increased during the analyzed period. The EU's share of the agrifood export became higher than that of its share of the total Hungarian exports (84.92\% versus 79.96\% in 2015-2019). Regarding the import side, Hungary almost entirely imports agri-food products from the other member states, while the import of non-food products is more diversified $(92.45 \%$ versus $76.23 \%)$.

The international competitiveness of the agri-food trade can be illustrated by the development of the imports and exports, as well as their balance. Figure 6 gives an overview of their development from 2000 to 2019. Both imports and exports increased remarkably, and Hungarian agri-food trade balance was always positive. 


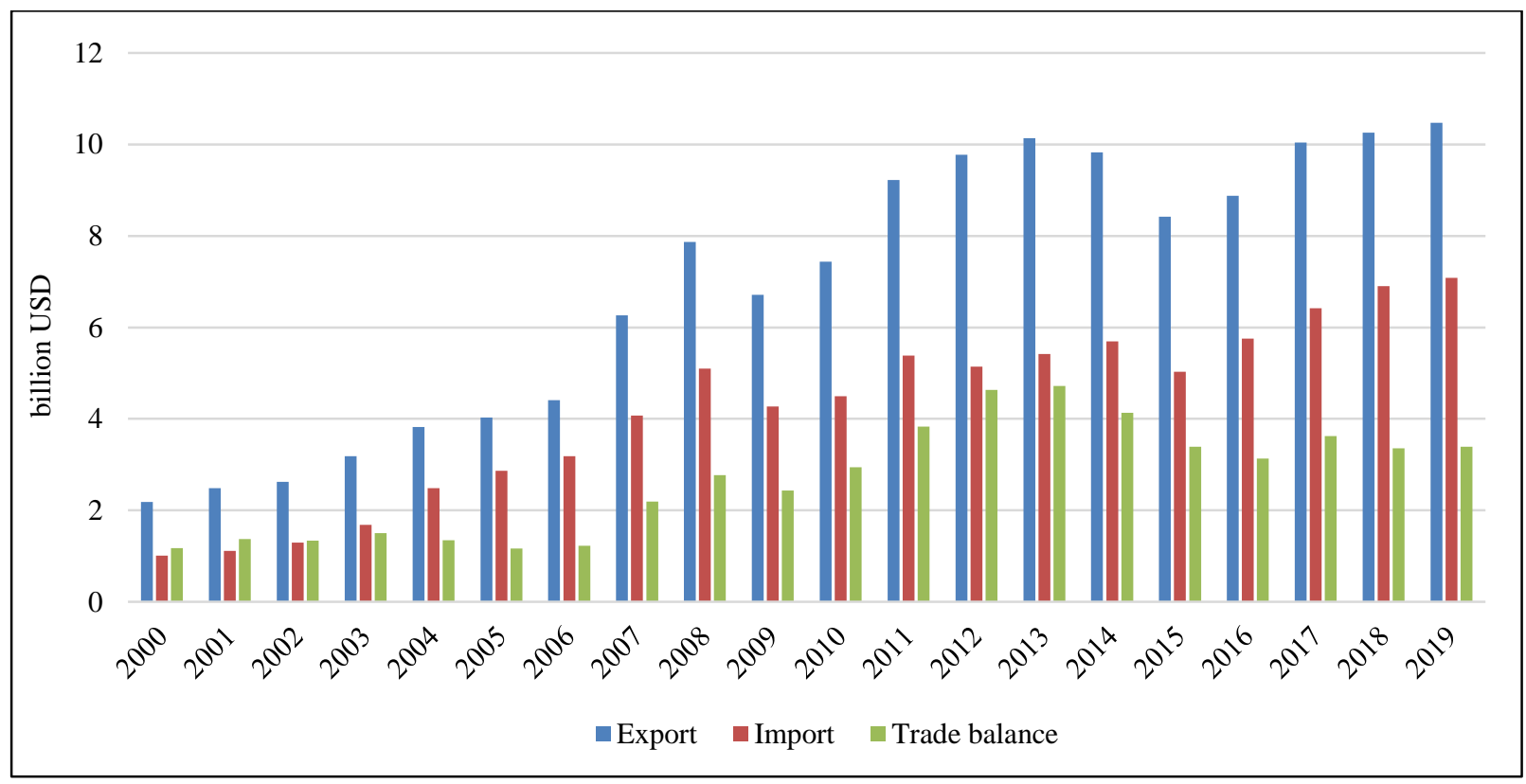

Figure 6. Hungarian agri-food exports, imports, and trade balance in billion USD, 2000-2019; Source: Author's composition based on WITS [18]

Altogether two declines can be identified. The first one took place in 2009, which was caused by the global financial crisis. It should be noted that exports decreased more than the imports, therefore, the trade surplus also decreased. This impact was even higher at the producer level, they have suffered $11.47 \%$ (Romania) - 32.02\% (Lithuania) price decline from 2008 to 2009 in the new member states [28]. Analyzing the financial impacts of this crisis at producer level, micro and small-sized farmers were hit the most [29]. The second case was caused by the EU sanctions against the Russian Federation. Russia was an important trade partner with Hungary, as well as with some other member states. When the exportation of agri-food was banned, Hungary needed to find new markets for its products. As that was the same for some other member states, agri-food prices sharply decreased. That crisis also impacted exports more than the imports and resulted in a lower trade surplus. Overall, these two crises significantly affected the Hungarian agri-food trade, however, the exportation was hit harder than importation.

Both import and export markets are concentrated. Hungary's five most important export partners account for a 52\% share of Hungarian exportation. Meanwhile, the TOP5 import partners account for 57\% of Hungary's importation (Figure 7). At the country level, Germany is Hungary's most important agri-food trade partner. On the export side, Germany is followed by Romania, Italy, Austria, and Poland. If we expand this list, we can find more member states (Slovak and Czech Republic, the Netherlands). On the import side, Poland, Slovak Republic, Austria, and the Netherlands follow Germany. There are no surprises on the expanded list, Czech Republic, Italy, and Romania are on the 6-8th places.
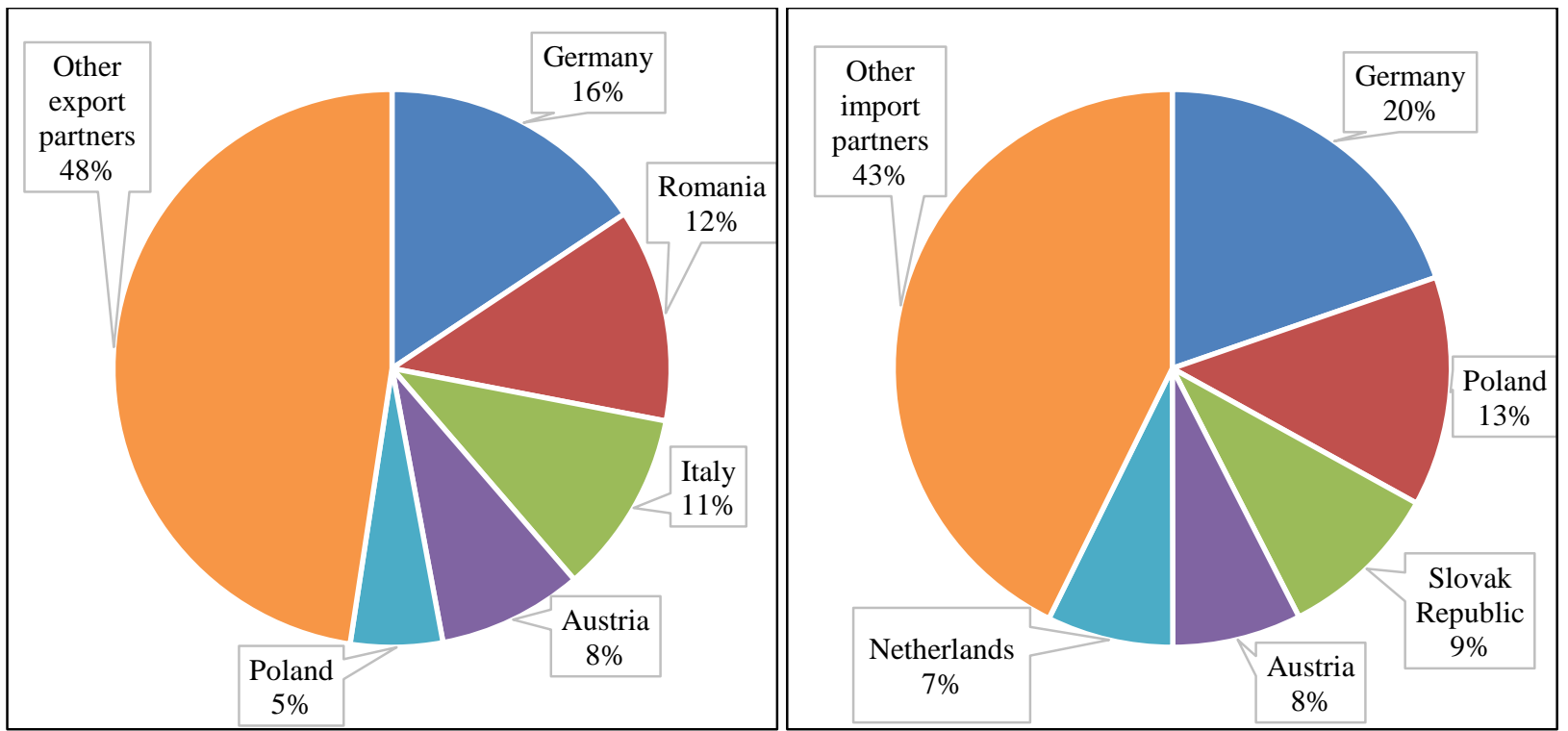

Figure 7. The major Hungarian agri-food import and export partners, 2019; Source: Author's composition based on WITS [18] 
More information can be collected by analyzing the product group level of agri-food trade. The export side is more concentrated, the share of the five main product groups is 50\% (Figure 8, left side). Those are cereals (10); meat and edible meat offal (02); residues and waste from food industries, prepared animal fodder (23); beverages, spirits and vinegar (22); and oil seeds and oleaginous fruits (12). As seen below, the major Hungarian export product group is cereals. Besides this product group, another raw material, oil seeds (12), can be found on this list. A long-term national goal should be to process these products and export them with a higher value-added.

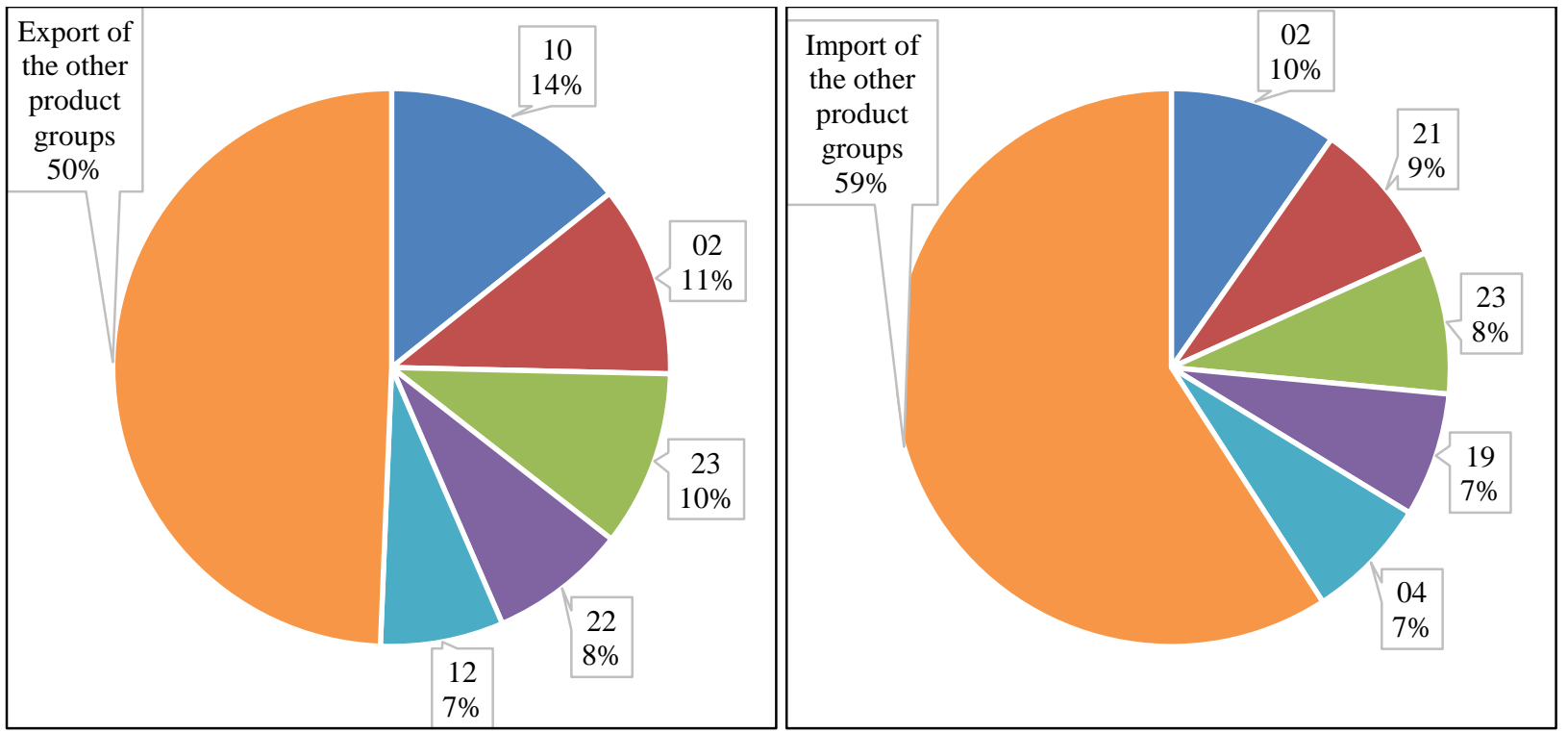

Figure 8. Major Hungarian agri-food import and export product groups, 2019; Source: Author's composition based on WITS [18]

On the import side, the major product groups are meat and edible meat offal (02); miscellaneous edible preparations (21); residues and waste from food industries, prepared animal fodder (23); preparations of cereals, flour, starch or milk, pastrycooks' products (19); and dairy produce, birds' eggs, natural honey (04). Their share is 41\% (Figure 8, right side). Unlike the major export products, all the major import products are processed goods. It would be great to change this trade structure, as it is unfavorable to Hungary. However, it should be highlighted that deep changes should be government initiated, including different incentives, exceptions, infrastructural investments, and foreign investment attractions [15].

Regarding the ongoing coronavirus pandemic, only limited official data is available. The agricultural production slightly decreased in quantity but increased in value in 2020 compared to 2019 [30]. According to the latest available national data on the agricultural and food industrial trade (nine months of 2020), there is no significant sign that the recent crisis caused the same agri-food trade decline as the two previous crises did. Moreover, contrary to the expectations, agri-food export, as well as import, increased in the first nine months of 2020 when compared to the previous year (Table 4). The expansion of exportation was larger than the increase of importation, resulting in an even higher trade surplus.

Table 4. The impacts of the pandemic on the agri-food trade [31]

\begin{tabular}{lcccc}
\hline & \multicolumn{2}{c}{ Export } & \multicolumn{2}{c}{ Import } \\
\cline { 2 - 5 } & Jan-Sep 2019 & Jan-Sep 2020 & Jan-Sep 2019 & Jan-Sep 2020 \\
\hline Agri-food trade (million euro) & 6,992 & 7,167 & 4,604 & 4,724 \\
\hline
\end{tabular}

In addition to the increase of imports and exports, world commodity prices also remained stable [6]. This further strengthens the fact that the COVID-19 pandemic had different impacts on the agri-food trade than the previous two crises. Moreover, the agri-food sector seems to be more crisis-resistant due to the higher supply chain flexibility and, in the case of Hungary, the highly integrated EU markets. However, these impacts were different along the supply chain, e.g. supermarkets face increased demand, while the HoReCa (Hotels, Restaurants, Cafés) sector has almost entirely stopped. These problems have exacerbated the need for self-sufficiency in the food importer countries [32].

Contrary to some previous results, positive agri-food trade balance provides mostly advantages, such as higher national food security and better opportunities for exportation. However, achieving a higher value-added should be a strategic goal. 


\section{Conclusions and Recommendations}

Based on the related literature, the common impacts of the last two crises were (global financial crisis and EU sanctions against Russia) lower food security and higher prices. These were particularly harmful to countries with agrifood trade deficits and less developed countries. The former may face food shortages and food supply problems, while the latter may lead to malnutrition and possibly even hunger among the poorer households. Therefore, different government policies aimed at more efficient production are recommended. This can reduce foreign dependency, increase food security, as well as contribute to a more crisis-resistant agri-food sector. Increased production may lead to lower prices that can help poorer households access a sufficient amount of food.

We should differentiate between countries with an agri-food trade surplus and countries with an agri-food trade deficit because their crisis-related problems are different. Countries with a negative agri-food trade balance could be more vulnerable to any crises, especially if it causes trade restrictions. Emerging markets and less developed countries, in particular, are exposed to such events. At the commodity level, raw materials and perishable products were affected more than processed or less perishable goods.

Hungary has a relatively large agri-food sector that produces more than what the country needs. This resulted in a positive trade balance during the whole analyzed period (2000-2019). Hungary's major trade partners are the other EU member states, and the shares of the five major partners are 52\% for exportation and $57 \%$ for importation. At the product group level, cereals are the country's major export products, followed by meat products, residues and waste from food industries, prepared animal fodder, beverages, spirits, vinegar, and oil seeds and oleaginous fruits. The import side is dominated by processed products such as meat and edible meat offal or miscellaneous edible preparations. It would be advantageous to export more processed products in the future. However, it should be highlighted that cereals and oilseeds drove Hungarian exports during the global financial crisis in 2008 [33].

A positive trade balance could have been problematic when certain trade restrictions were applied, but this turned out to be only temporary. It seems that the COVID-19 pandemic has not caused the same agri-food trade decline, which the global financial crisis and the Russian embargo did, despite the strict, initial lockdown measures. According to the results, Hungary enjoyed only the benefits of the agri-food trade surplus: national food security was insured, and exports increased more than imports. The agri-food sector turned out to be more crisis-resistant than the other sectors of the Hungarian economy.

There are many future research topics available. First of all, more detailed datasets can be used, either HS-4 or even HS-6 level. In addition to that, these calculations can be repeated later using official data for 2020. This may contribute to a deeper analysis of the COVID-19 pandemic impact.

\section{Declarations}

\subsection{Data Availability Statement}

All calculations are based on publicly available data sources (FAO database, Hungarian National Statistical Office website, World Bank's WITS database).

\subsection{Funding}

The author received no financial support for the research, authorship, and/or publication of this article.

\subsection{Acknowledgements}

The author wishes to thank Earl Ryan Kovacs for his edits and thorough proofreading.

\subsection{Declaration of Competing Interest}

The author declare that they have no known competing financial interests or personal relationships that could have appeared to influence the work reported in this paper.

\section{References}

[1] FAO (2017). The future of food and agriculture - Trends and challenges. Food and Agriculture Organization, Rome, Italy.

[2] Von Braun, J. (2008). Food and financial crises: Implications for agriculture and the poor. Vol. 20. International Food Policy Research Institute. Washington, DC., USA.

[3] Crescimanno, M., Galati, A., \& Bal, T. (2014). The role of the economic crisis on the competitiveness of the agri-food sector in the main Mediterranean countries. Agricultural Economics (Zemědělská Ekonomika), 60 (2), 49-64. doi:10.17221/59/2013agricecon. 
[4] Kalinina, K. (2017). 3 years of embargo in Russia: The winners and losers, Russia Beyond, 6 August. Available online: https://www.rbth.com/business/2017/08/06/3-years-of-embargo-in-russia-the-winners-and-losers_816898 (accessed on January 2021).

[5] Liefert, W. M. \& Liefert, O. (2015). Russia's economic crisis and its agricultural and food economy. Choices, $30(1), 6$. Available online: https://www.jstor.org/stable/choices.30.1.12 (accessed on May 2021).

[6] World Bank (2020). Commodity Markets Outlook, April. World Bank report, Washington, DC., USA.

[7] Weersink, A., von Massow, M., Bannon, N., Ifft, J., Maples, J., McEwen, K., McKendree, M., Nicholson, C., Novakovic, A., Rangarajan, A., Richards, T., Rickard, B., Rude, J., Schipanski, M., Schnitkey, G., Schulz, L., Schuurman, D., SchwartzkopfGenswein, K., Stephenson, M., Thompson, J. \& Wood, K. (2020). COVID-19 and the agri-food system in the United States and Canada. Agricultural Systems, 103039. doi:10.1016/j.agsy.2020.103039.

[8] Aday, S., \& Aday, M. S. (2020). Impact of COVID-19 on the food supply chain. Food Quality and Safety, 4(4), 167-180. doi:10.1093/fqsafe/fyaa024.

[9] Mussell, A., Bilyea, T. \& Hedley, D. (2020). Agri-food supply chains and Covid-19: Balancing resilience and vulnerability. Independent Agri-Food Policy Note. Agri-Food Economic Systems. Guelph Ontario, USA.

[10] Morsy, H., Salami, A., \& Mukasa, A. N. (2021). Opportunities amid COVID-19: Advancing intra-African food integration. World Development, 139, 105308. doi:10.1016/j.worlddev.2020.105308.

[11] Heck, S., Campos, H., Barker, I., Okello, J. J., Baral, A., Boy, E., Brown, L. \& Birol, E. (2020). Resilient agri-food systems for nutrition amidst COVID-19: evidence and lessons from food-based approaches to overcome micronutrient deficiency and rebuild livelihoods after crises. Food Security, 12(4), 823-830. doi:10.1007/s12571-020-01067-2.

[12] Verpoorten, M., Arora, A., Stoop, N. \& Swinnen, J. (2013). Self-reported food insecurity in Africa during the food price crisis. Food Policy, 39, 51-63. doi:10.1016/j.foodpol.2012.12.006.

[13] Poppe, K. (2020). Covid-19 will Change the Agri - food System - but how? EuroChoices, 19(3), 20 - 25. doi:10.1111/1746$692 x .12276$.

[14] Daglis, T., Konstantakis, K. N. \& Michaelides, P. G. (2020). The impact of Covid-19 on agriculture: evidence from oats and wheat markets. Studies in Agricultural Economics, 122(3), 132-139. doi:10.7896/j.2058.

[15] Dokić, D., Gavran, M., Gregić, M. \& Gantner, V. (2020). The Impact of Trade Balance of Agri-Food Products on the State's Ability to Withstand the Crisis. HighTech and Innovation Journal, 1(3), 107-111. doi:10.28991/HIJ-2020-01-03-02.

[16] Fan, S., Teng, P., Chew, P., Smith, G., \& Copeland, L. (2021). Food system resilience and COVID-19 - Lessons from the Asian experience. Global Food Security, 28, 100501. doi:10.1016/j.gfs.2021.100501.

[17] Yeung, M. - Kerr, W.A. (2021): Canadian Agri-Food Export Opportunities in a Covid-19 World. The School of Public Policy Publications, SPP Briefing Paper, 14(5), p. 39.

[18] WITS (2020). World Bank's World Integrated Trade Solution database. Available online: http://wits.worldbank.org/ (last accessed on January 2020).

[19] HNSO (2020). Agricultural census - FSS 2020. Hungarian National Statistical Office. Available online: https://www.ksh.hu/agricultural_census?lang=en (accessed on December 2020).

[20] Mizik, T. (2019). The Economic Impacts of the 2013 Reform on the Hungarian Agriculture. Research for Rural Development, 2, 14-20. doi:10.22616/rrd.25.2019.043.

[21] HNSO (2020). 2.1.7.2. Number of employed persons by industries, economic branches and sex - NACE Rev. 2. Available online: http://www.ksh.hu/docs/eng/xstadat/xstadat_annual/i_qlf005a.html (accessed on January 2021).

[22] HNSO (2020). 3.1.4. Value and distribution of gross value added by industries. Available online: http://www.ksh.hu /docs/eng/xstadat/xstadat_annual/i_qpt002a.html (accessed on January 2021).

[23] FAO (2020). Crops. Food and Agriculture Organization. Available online: http://www.fao.org/faostat/en/\#data/QC (accessed on December 2020).

[24] FAO (2020). Livestock Primary. Food and Agriculture Organization. Available online: http://www.fao.org/faostat/en/\#data/QL (accessed 15 December 2020).

[25] Vinklerné Rajcsányi, K. (2017). A magyar sertéstartó egyéni gazdaságok pénzügyi elemzése /Financial analysis of the Hungarian individual pig farms/ PhD dissertation, Szent István Egyetem, Gödöllö, Hungary.

[26] Czerván, Gy. (2017). A szarvasmarha ágazat agrárgazdasági helyzete/The agricultural situation of the cattle sector/. Presentation, Association of Hungarian Simmental, Professional Days, Kocsér, Hungary, 22.06.2017. 
[27] FAO (2020). Livestock Processed. Food and Agriculture Organization. Available online: http://www.fao.org/faostat /en/\#data/QP (accessed on December 2020)

[28] FAO (2021): Producer Prices. Food and Agriculture Organization. Available online: http://www.fao.org/faostat/en/\#data/PP (accessed on May 2021).

[29] Fáró, J., Lakatos, M., \& Karai, É. (2020). Financial position of Hungarian agricultural companies before, during, and after the global financial crisis. Serbian Journal of Engineering Management, 5(1), 29-39. doi:10.5937/sjem2001029f.

[30] Ehretné Berczi, I. (2020a). Statisztikai jelentések. A mezőgazdaság 2020. évi teljesítményének I. előrejelzése /Statistical reports. First Forecast of the Hungarian Agricultural Performance in 2020/. 10(1), 11.

[31] Ehretné Berczi, I. (2020b). Statisztikai jelentések. Az élelmiszer-gazdaság külkereskedelme 2020. év I-IX. Hónap/Statistical reports. Foreign trade of the food economy January-September 2020, 23(4), 29.

[32] Doucha, T. (2021). Consequences of the COVID-19 Outbreak for the Czech Agri-food Sector in 2020. Zagadnienia Ekonomiki Rolnej, 366(1), 14-18.

[33] Darvasné Ördög, E.-Juhász, A.-Tunyoginé Nechay, V.-Wagner, H. szerk. (2009). A válság hatása a magyar élelmiszergazdasági külkereskedelemre nemzetközi összehasonlításban /The impacts of the crisis on the foreign trade of the Hungarian food economy in an international context. Agrárgazdasági tanulmányok, 8. szám, Agrárgazdasági Kutató Intézet, Budapest, Hungary. 